Gut, 1972, 13, 501-512

\title{
Two types of Zollinger-Ellison syndrome: immunofluorescent, cytochemical and ultrastructural studies of the antral and pancreatic gastrin cells in different clinical states
}

\author{
JUlia M. POLAK, B. STAGgí, AND A. G. E. PEARSE \\ From the Department of Histochemistry, Royal Postgraduate Medical School, London
}

SUMMARY In this survey the antral, pancreatic and, where present, the neoplastic gastrin cells, were studied in eight cases of the Zollinger-Ellison syndrome. The antral $\mathrm{G}$ cells alone were studied in one case of Z-E syndrome, seven cases of simple duodenal ulcer, and five cases of pernicious anaemia.

The Z-E cases were divided into two numerically equal groups. The first group had 'short' histories, high serum gastrin levels, and profound antral $G$ cell hyperplasia. The second group had 'long' histories, relatively lower serum gastrin levels, normal antral $G$ cells, and either pancreatic D cell hyperplasia or gastrinoma.

Antral $\mathrm{G}$ cell hyperplasia, with maximal gastrin storage and normal serum gastrin levels, was found in the duodenal ulcer cases. Antral $G$ cell hyperplasia with minimal storage and high serum gastrin levels was observed in the cases of pernicious anaemia.

On the basis of our findings we propose that there exist at least two distinct types (or perhaps stages) of the Z-E syndrome. Suggestions for their pathogenesis are offered.

The combination of gastric hypersecretion, intractable peptic ulceration, and non-insulin-producing pancreatic islet cell tumours was noted by Sailer and Zinniger (1946), Forty and Barrett (1952), and by Strom (1953). It remained for Zollinger and Ellison (1955) to describe accurately the syndrome which now bears their names, and about which so much has been written. By 1964 (Ellison and Wilson, 1964) 260 cases had been recorded in the literature and the number now exceeds 1000 . Many reports have appeared which deal with new aspects of the syndrome and its causation (Priest and Alexander, 1957; Summerskill, 1959; Grossman, Tracy, and Gregory, 1961; Zollinger, Elliott, Endahl, Grant, Goswitz, and Taft, 1962; Selli, Baglioni, and Castrini, 1963; Sircus, 1964; Hallenbeck, 1966; Guida, Todd, Moore, and Beal, 1966; Cavallero, Solcia, and Sampietro, 1967; Friesen, Bolinger, Pearse,

'Present address: Surgical Unit, University College Hospital Medical School, London.

Received for publication 9 May 1972. and McGuigan, 1970; Creutzfeldt, Arnold, Creutzfeldt, Feurle, and Ketterer, 1971).

The possibility that an ulcerogenic humoral factor of pancreatic islet origin is responsible for the gastric hypersecretion and peptic ulceration was first suggested by Poth, Manhoff, and Deloach (1948), and reaffirmed by Zollinger and Ellison (1955). The extraction of a gastrin-like factor from a pancreatic tumour by Gregory, Tracy, French, and Sircus (1960) suggested that the ulcerogenic factor might be identical with the antral hormone gastrin, the latter identified as a heptadecapeptide by Gregory, Hardy, Jones, Kenner, and Sheppard (1964) and Gregory and Tracy (1964). This identity was confirmed subsequently by Gregory, Grossman, Tracy, and Bentley (1967).

The successful production of antibodies to gastrin (McGuigan, 1968) led to the development of radioimmunoassay techniques by which elevated levels of gastrin were detected in the serum of patients with pancreatic tumours and Z-E syndrome 
(McGuigan and Trudeau, 1968). Identification of a gastrin-secreting cell in human and porcine antral mucosa was made by McGuigan (1968) and subsequently Bussolati and Pearse (1970), using a double-staining technique on single sections, showed that the argyrophil $G$ cells described by Solcia, Vassallo, and Sampietro (1967) were indeed responsible for the secretion of gastrin.

Establishment of the relationship between gastrin and the gastric secretagogue from Z-E tumours reinforced the concept of the 'entero-insular axis' and stimulated investigation of a third cell type in the endocrine pancreas, recognized in the islets of man and other animals by Bloom (1931) and later by Thomas (1937). This argyrophil cell was designated $\alpha_{1}$ by Hellman, Rothman, and Hellerström (1962) and Peterson, Hellerström, and Hellman (1962). Subsequently, it was described as the D cell by Fujita $(1964,1968)$ and by Solcia and Sampietro (1965). Immunofluorescence identification of gastrin in the pancreatic D cell was made by Lomský, Langr, and Vortel (1969), and by Greider and McGuigan (1971), and the way thus became clear for further studies on the mechanism of the Z-E syndrome.

This paper describes the application of cytochemical, immunofluorescence, and ultrastructural techniques to antral, pancreatic, and tumour tissues from cases of Z-E syndrome, to antral tissues from duodenal ulcer and pernicious anaemia cases, and to duodenal tissues from cases of duodenal ulcer.

\section{Materials and Methods}

Samples from the antral and fundic mucosa of the stomach (nine cases) and from the body or tail of the pancreas (eight cases) were obtained from patients with Zollinger-Ellison syndrome, proven clinically and by radioimmunoassay. Where present (three cases) tumour tissues were taken for study. Samples of antral and/or duodenal mucosa were obtained from seven cases of simple duodenal ulceration, and from five cases of pernicious anaemia. These last were included in order to provide a control series for acid inhibition. Small pieces of each of the tissues were processed in various ways for different purposes, as described below.

\section{IMMUNOFLUORESCENCE}

\section{Gastric and duodenal mucosa}

Samples were fixed at $4^{\circ}$ in $4 \%$ methanol-free formaldehyde for three to six days. They were then dehydrated, cleared, and embedded in $56^{\circ} \mathrm{mp}$ paraffin wax. Preparation of methanol-free formaldehyde followed directions given by Polak, Bussolati, and Pearse (1971). Sections were cut at $5 \mu \mathrm{m}$ and picked up from water on glycerin-albumin-coated slides. They were dried at $37^{\circ}$ for 24 hours and dewaxed in light petroleum.

\section{Pancreas, gastrinomas}

Small pieces of tissue were quenched in Arcton (Freon) 22 at $-158^{\circ}$ and subsequently $5 \mu \mathrm{m}$ cryostat sections were prepared.

\section{Technique}

An indirect method was employed (Coons, Leduc, and Connolly (1955) using rabbit antihuman gastrin I serum for the first layer and fluorescein-labelled goat antirabbit IgG globulin (Hyland) for the second layer. Formaldehyde-fixed, paraffin-embedded sections were used for the demonstration of $G$ cells in the antrum and duodenum (Bussolati and Pearse, 1970) and unfixed cryostat sections for the demonstration of the gastrin-producing $\mathrm{D}$ cells of the pancreas (Greider, Bencosme, and Lechago, 1970). The following controls were used: (1) antihuman gastrin with added excess of synthetic gastrin I, followed by fluorescein-labelled antiglobulin; (2) normal rabbit serum followed by the second layer; (3) fluorescein-labelled goat antirabbit globulin alone; (4) observation of untreated sections by fluorescence microscopy.

Sections were examined on a Laborlux microscope fitted with a quartz-iodine lamp and photographed with Ilford FP4 film.

\section{PRODUCTION OF ANTISERA}

Antisera to synthetic human gastrin I residues 2 to 17 , were raised in four rabbits by immunization with the hormone conjugated to crystalline bovine plasma albumin. The conjugation was carried out by carbodiimide condensation using water-soluble 1-ethyl-3-(3-dimethyl aminopropyl) carbodiimide hydrochloride (Goodfriend, Levine, and Fasman, 1964), and yielded a product in which an average of 10 molecules of synthetic human gastrin were linked per molecule. Each rabbit received an amount of the conjugate equivalent to $2 \mathrm{mg}$ of synthetic human gastrin, the antigen being injected into the footpads as an emulsion in Freund's complete adjuvant. The immunizations were repeated three times at three monthly intervals, and the rabbits were bled after the first and all subsequent booster injections.

Following this course of injections it was found that all the rabbits had antibodies to synthetic human gastrin. One gave an antiserum of sufficiently high avidity and titre to be used in a radioimmunoassay, and the remaining antisera were used in the immunofluorescence studies. 


\section{OPTICAL MICROSCOPIC METHODS}

\section{Fixation and embedding}

Small blocks of antral, fundic, and duodenal mucosa, and of pancreas, were fixed for 24 hours in the following fixatives: formol-saline; $6 \%$ glutaraldehyde in $0.1 \mathrm{M}$ phosphate buffer, $p \mathrm{H} 7 \cdot 4$; Bouin's fluid; glutaraldehyde-picric acid (Solcia, Vassallo, and Capella, 1968). All blocks were subsequently washed in water, dehydrated, cleared, and embedded in $56^{\circ} \mathrm{mp}$ paraffin wax. Sections $(5 \mu \mathrm{m})$ from appropriate (correctly fixed) blocks were processed by methods selective for the secretory granules of gastrointestinal or pancreatic endocrine cells.

\section{Dark-field observation}

Fresh frozen cryostat sections were studied by darkfield luminescence which demonstrates pancreatic $\alpha_{2}$ (A) cells (Cavallero and Solcia, 1964) and intestinal enteroglucagon cells (Polak, Bloom, Coulling, and Pearse, 1971).

\section{Staining methods}

For gastrointestinal endocrine cells sections were stained with $\mathrm{H} \& \mathrm{E}$; toluidine blue at $p \mathrm{H} 5.0$ before and after acid treatment $\left(0 \cdot 2 \mathrm{~N}-\mathrm{HCl}, 60^{\circ}, 30\right.$ minutes to two hours; Solcia et al, 1968); lead haematoxylin (Solcia, Capella, and Vassallo, 1969a); the xanthydrol method for tryptophan and 5-hydroxytryptamine (Solcia, Sampietro, and Capella, 1969b); the Masson-Fontana method for enterochromaffin granules (Pearse, 1960, 1972); silver impregnation methods (Grimelius, 1968; Sevier and Munger, 1965).

For pancreatic endocrine cells the following methods were used: aldehyde-fuchsin (Gomori, 1952) for islet B cell granules; phosphotungstic acid haematein (PTAH) (Terner, Gurland, and Gaer, 1964), the $O$-phthalaldehyde method (Takaya, 1970), and dark-field luminescence for $A$ cell granules; toluidine blue metachromasia (Manocchio, 1964) for D cells; lead haematoxylin with and without prior acid treatment (Solcia et al, 1969) for A and D cells; Grimelius (1968) silver for A cell granules.

All these techniques were photographed on Ilford Pan F film.

\section{ELECTRON MICROSCOPIC METHODS}

Small blocks of tissue were fixed, immediately after removal, in $3 \%$ glutaraldehyde in $0.1 \mathrm{M}$ phosphate buffer at $p \mathrm{H} 7.6$ for two hours at $4^{\circ}$. Excess fixative was removed from the samples by repeated washing in $0 \cdot 1 \mathrm{M}$ phosphate buffer containing $0 \cdot 1 \mathrm{M}$ sucrose. They were then dehydrated in ethanol and epoxypropane and finally embedded in Araldite mixture. With some blocks a double fixation procedure was carried out, using postfixation with osmium tetroxide at $4^{\circ}$ for two hours (Millonig, 1962). Sections were stained by lead citrate and uranyl acetate, and viewed in an AEI 6B electron microscope.

\section{QUANTITATIVE STUDIES}

These were carried out with colour transparencies of immunofluorescence preparations, using a television image analyser constructed by the Medical Research Council Cyclotron Unit, Hammersmith Hospital. In this instrument a television camera scans the photomicrographs and produces a coloured image on a monitor. A particular colour is selected by the operator to represent a particular density range, and up to seven colours can be used. By electronic means, the relative area occupied by each colour can then be determined.

\section{RADIOIMMUNOASSAY}

Synthetic human gastrin was iodinated with ${ }^{125}$ I by a modification of the chloramine-T method (Hunter and Greenwood, 1962), and purified by gel-filtration on Sephadex G-10. Preparations had specific activities in the range 300 to $500 \mu \mathrm{Ci} / \mu \mathrm{g}$.

Diluted Z-E plasma samples $(0 \cdot 1 \mathrm{ml})$ or standard amounts of synthetic human gastrin 5 to $100 \mathrm{pg} / 0 \cdot 1$ $\mathrm{ml}$ ) were assayed in duplicate, the total volume of the assay mixture being $0.5 \mathrm{ml}$. This also contained antiserum $(0.1 \mathrm{ml} ; 1 / 5000)$ and ${ }^{125}$ I-synthetic human gastrin $(0.1 \mathrm{ml} ; 2000$ to $3000 \mathrm{cpm})$. After incubation at $4^{\circ}$ for 48 hours the antibody-bound and free ${ }^{125} \mathrm{I}$-synthetic human gastrin fractions were separated with dextran-coated charcoal (Herbert, Lau, Gottlieb, and Bleicher, 1965).

The sensitivity of the assay permitted the detection of as little as $5 \mathrm{pg}$ of gastrin, and gave mean $( \pm$ SEM) fasting plasma gastrin levels of $87 \pm 9$ $\mathrm{pg} / \mathrm{nl}$ for normal subjects and $84 \pm \mathrm{pg} / \mathrm{ml}$ for patients with duodenal ulcers.

\section{Results}

Marked hyperplasia of the antral G cells was found in five of the nine Z-E cases studied. In four of these five cases pancreatic samples were available and the pancreatic $D$ cells in two cases were normal by histological and immunofluorescence criteria. In the other two cases some degree of D cell hyperplasia was present. This ranged from a diffuse hyperplasia of the islet cells, through a true $D$ cell hyperplasia (a disproportional number of $\mathbf{D}$ cells 
distributed throughout the islet rather than in their normal peripheral location) to frank neoplasia of the pancreatic gastrin-producing cells. One of the cases with normal $G$ cells in the antrum had a gastrin-producing tumour in the wall of the stomach. In the fundic mucosa we found no abnormalities other than a diffuse hyperplasia of the enterochromaffin-like cells which accompanied antral $G$ cell hyperplasia.

\section{ANTRAL AND DUODENAL MUCOSA}

Sections from the duodenal ulcer and Z-E cases stained with $H$ \& $E$ showed, in the majority of cases, marked inflammation, intestinal type metaplasia, microhaemorrhages, and erosion of the mucosa, mainly in the neighbourhood of ulcers. In cases with hyperplasia of $G$ cells an increased number of clear cells could be seen in the midzone of the glands. These were even more readily visible in thick $(1 \mu \mathrm{m})$ resin-embedded sections stained with toluidine blue. Clear cells could readily be seen also in antral samples from the pernicious anaemia cases. ${ }^{1}$

\section{IMMUNOFLUORESCENCE STUDIES}

Hyperplasia of $G$ cells was present in four of the $Z$-E cases while in the other cases they were present in normal numbers. In the hyperplastic antra the $\mathrm{G}$ cells occupied most of the midzone of the pyloric glands and they extended also into the deeper zone (Fig. 1). In one of the cases G-cell microadenomata

${ }^{1}$ Pernicious anaemia results to be published elsewhere (Polak, Hoffbrand, Read, and Pearse, 1972).

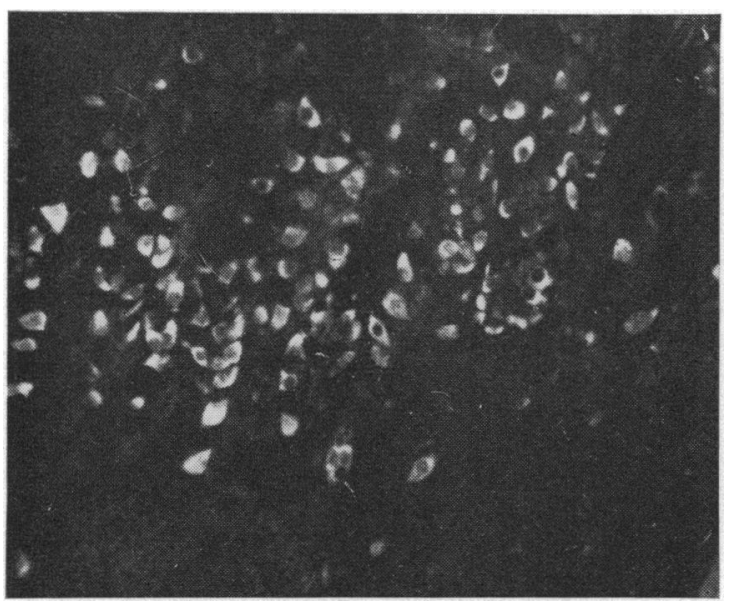

Fig. 1 Antral $G$ cell hyperplasia in a case of $Z-E$ syndrome. The cells are larger than normal and greatly increased in number, forming a band across the midzone of the pyloric glands. Antigastrin immunofluorescence $\times 165$.

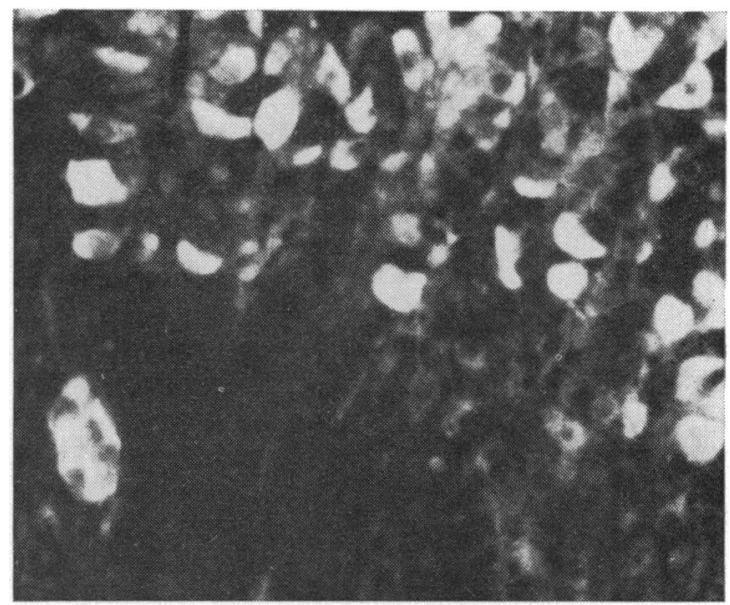

Fig. 2 Antral $G$ cell hyperplasia in Z-E syndrome. In the lower zone of the pyloric glands microadenomata can be observed. Most of the cells are full of gastrin. Antigastrin immunofluorescence $\times 365$.

were present (Fig. 2) and in the hyperplastic cases the cells were always larger than normal. In all seven cases of duodenal ulcer it was possible to find $G$ cells in increased numbers in the antral mucosa, and in the duodenal mucosa of these cases it was possible to find $G$ cells without difficulty. (In the normal duodenal mucosa $\mathrm{G}$ cells can also be found but they are few and far between.) In the antral mucosa of the pernicious anaemia cases there was a true hyperplasia of the $G$ cells but in all cases immunofluorescence was confined to a crescent or rim (Fig. 3),

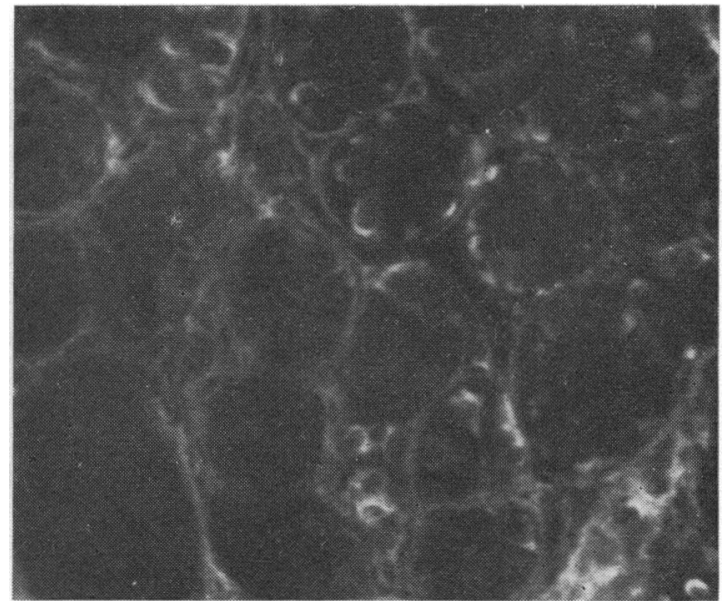

Fig. 3 Antral $G$ cell hyperplasia in a case of pernicious anaemia. Most of the cells contain only a small amount of gastrin, which forms a fluorescent crescent or rim in those cells which contain it. Antigastrin immunofluorescence $\times 260$. 
indicating a high output of gastrin in the absence of acid inhibition.

Control sections showed no fluorescence or only weak fluorescence of a few enterochromaffin cells.

HISTOLOGICAL AND CYTOCHEMICAL STUDIES The hyperplastic and normal $G$ cells in duodenal ulcer and Z-E syndrome were metachromatic with the $\mathrm{HCl}$-basic dye method. They stained bluishblack with lead haematoxylin and brown with the Grimelius silver impregnation. Masson-Fontana and Sevier-Munger techniques gave negative results. The xanthydrol reaction for tryptophan and 5-HT gave a strongly positive result in enterochromaffin cells but was only weakly positive in the $G$ cells.

ELECTRON-MICROSCOPICAL STUDIES

The endocrine cells of the mucosa in the hyperplastic Z-E cases were notably more numerous than usual. This increase was largely but not entirely confined to the easily recognizable $G$ cells (Fig. 4). In the duodenal ulcer cases the cells were mainly

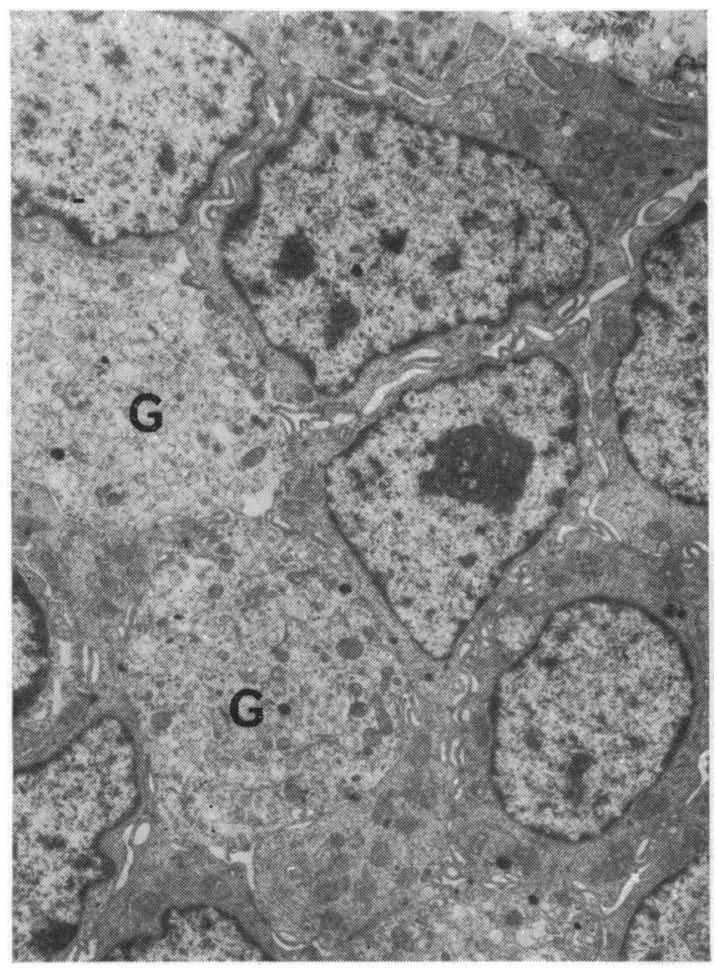

Fig. 4 Ultrastructure of the antrum in Z-E syndrome. Parts of four $G$ cells can be observed. They show the characteristic granules most of which have low electron density or even total lack of protein content. $\times 5400$. fully granulated, the granules being clearly in different stages of maturity.

\section{QUANTITATIVE STUDIES}

The results for normal antral $G$ cell cases are shown in the television image (Fig. 5), where the middle zone of the glands has been selected for quantitation. This should be compared with Fig. 6 which represents

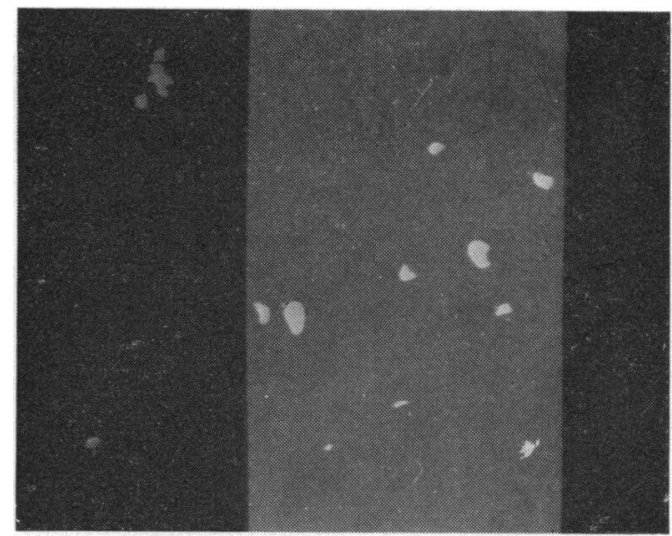

Fig. 5 Television image from a slide of the antral midzone in a case of $Z-E$ syndrome with normal $G$ cell content (immunofluorescence).

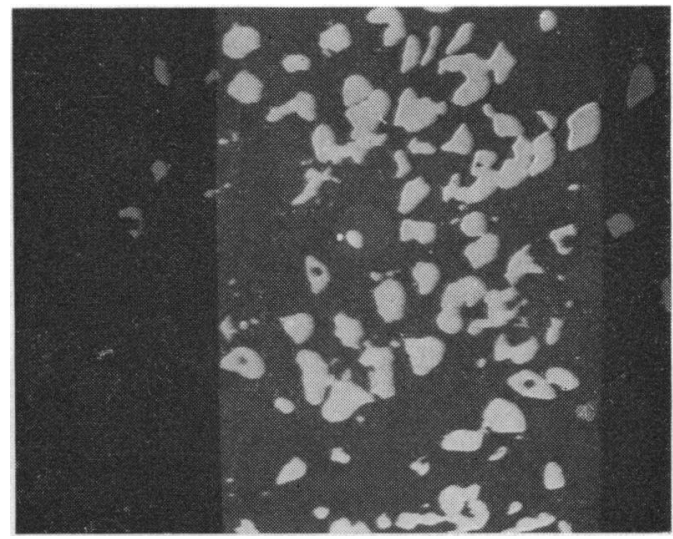

Fig. 6 Television image from a slide of the antral midzone in a case of $Z-E$ syndrome with $G$ cell hyperplasia (immunofluorescence).

the middle zone of the pyloric glands from a Z-E case with $\mathrm{G}$ cell hyperplasia, at an identical magnification. The readings obtained from the analyser appear in Table I. For the whole thickness of the pyloric glands the degree of hyperplasia was thus approximately $\times 20$; for the midzones it reached over 30 times the normal figure. 


\begin{tabular}{lcc}
\hline & Cells & Background \\
\hline $\begin{array}{l}\text { Normal Antral G Cells } \\
\text { Whole thickness }\end{array}$ & 900 & 155000 \\
Midzone only & 600 & 66000 \\
& & \\
Hyperplastic G Cells (Z-E) & 20000 & 139000 \\
Whole thickness & 18000 & 62900 \\
\hline Midzone only &
\end{tabular}

Table I Readings from the analyser

\section{PANCREAS}

Two of the three cases of Z-E in which the pancreas was involved showed hyperplasia of the $D$ cells. In one case the A cells were also affected to a moderate degree.

\section{Immunofluorescence studies}

The normal distribution of $D$ cells (gastrincontaining cells) was found in those cases without involvement of the pancreas. As can be seen in Fig. 7, where there is minimal hyperplasia, the $\mathbf{D}$ cells are almost exclusively situated at the periphery of the islet. In the two cases of gross D cell hyperplasia the number and size of the islets, as far as could be determined, appeared to be normal. The $\mathrm{D}$ cells in these cases were not only present in increased numbers, they were significantly larger than normal, and distributed throughout the islet rather than restricted to its periphery. Control sections showed no specific fluorescence.

\section{Histological and cytochemical studies}

Both normal and hyperplastic D cells reacted metachromatically with toluidine blue. They were stained specifically by the Hellerström-Hellman silver impregnation technique.

\section{Ultrastructural studies}

Three types of endocrine cell were easily distin-

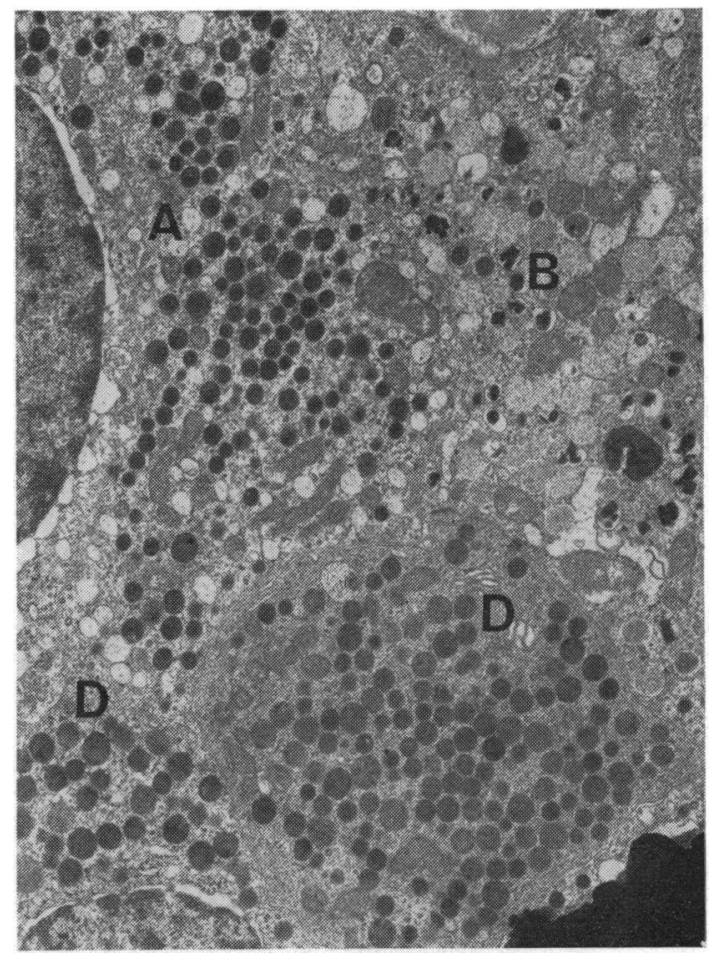

Fig. 8 Ultrastructure of a pancreatic islet from a case of $Z-E$ syndrome with extreme $D$ cell hyperplasia.

Part of a B cell, an A cell, and two D cells are shown. The very distinct granulation of these last should be compared with that of the antral $G$ cells in Figure 4.

guishable in the pancreatic islets of both normal and pathological cases. Our findings in the normal pancreas were essentially similar to those of Greider et al (1970) and of Deconinck, Potvliege, and

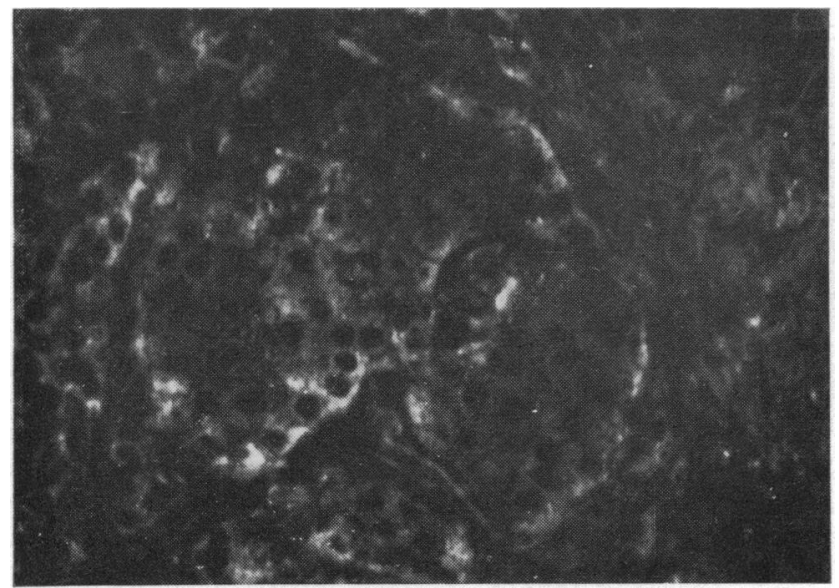

Fig. 7 Pancreatic islet from a case of $Z-E$ syndrome. Shows normal (peripheral) distribution of $D$ cells and a minimal (early) degree of hyperplasia. Antigastrin immunofluorescence $\times 320$. 
Gepts (1971). In those cases which showed D cell hyperplasia by optical microscopy we obtained ultrastructural confirmation. The D cells (Fig. 8) were distinguished by the presence of secretory granules having an overall density lower than that of the A granules, with a limiting membrane closely attached to the core. The D cell granules varied in diameter from 180 to $350 \mathrm{~nm}$ (Fig. 8), whereas the antral G cell granules measure 150-180 nm (see Table IV). The secretory granules of A and B cells were clearly distinguishable by their known characteristics.

\section{Quantitative studies}

In Fig. 9 is shown the appearance, on the television screen, of a pancreatic islet from one of the cases of Z-E syndrome with minimal involvement of the pancreas. The immunofluorescent $D$ cells are seen mainly, but not exclusively, at the periphery of the islet. The companion figure (Fig. 10) photographed at the same total magnification on the screen, shows immunofluorescent $D$ cells from one of the Z-E cases with D cell hyperplasia. The figures derived from image conversion analysis are shown in Table II.

\begin{tabular}{lll}
\hline & Cells & Background \\
\hline 'Normal' pancreatic islet & 2000 & 27700 \\
Hyperplastic islet & 6600 & 28000 \\
\hline
\end{tabular}

Table II Results from image conversion analysis

It can be seen that the degree of $D$ cell hyperplasia is $3.3 \times$ the 'normal' figure but the true normal can rate as low as a nil count per islet.

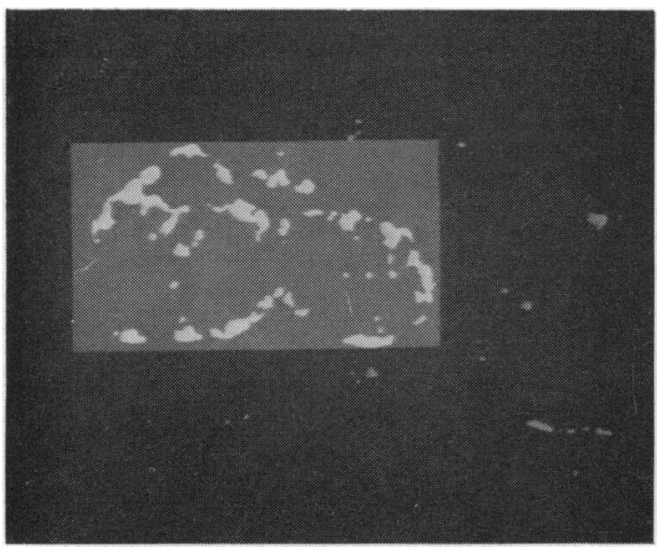

Fig. 9 Television image from a slide of a case of Z-E syndrome with 'normal' $D$ cell content of the pancreatic islets.

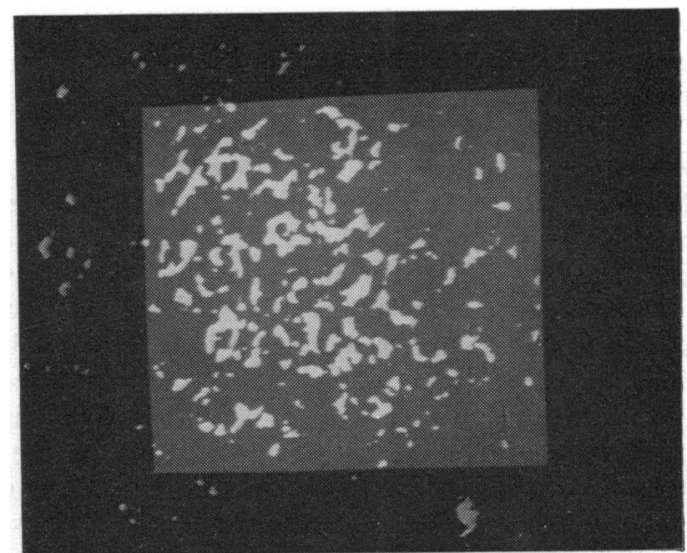

Fig. 10 Television image from a slide of a case of $Z-E$ syndrome with extreme pancreatic $D$ cell hyperplasia.

\section{Tumours}

In the series of eight cases there were two pancreatic gastrinomas and one gastrinoma of the stomach. Positive immunofluorescence with antigastrin sera was obtained in all three cases, and this is shown, for one of the cases, in Figure 11. There was a negative correlation between antral $\mathbf{G}$ cell hyperplasia and the presence of either pancreatic islet $D$ cell hyperplasia or of a gastrin-secreting tumour. That is to

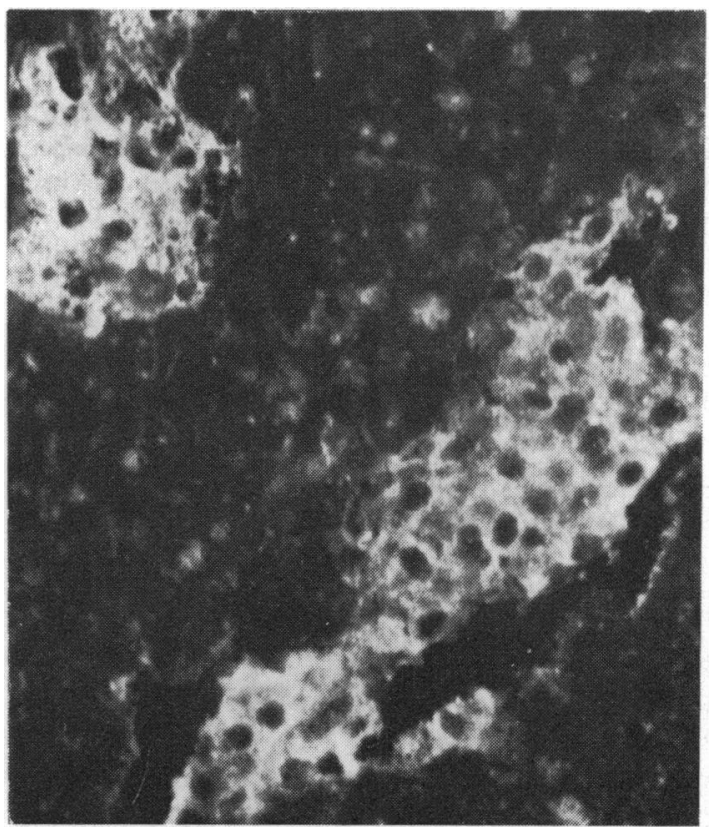

Fig. 11 Pancreatic gastrinoma in a case of Z-E syndrome. Shows masses of gastrin-containing cells in a loose stroma. Antigastrin immunofluorescence $\times 300$. 
say, in those cases in which antral $G$ cell hyperplasia was present there was minimal or no $D$ cell hyperplasia.

\section{RADIOIMMUNOASSAY}

The pre- and postoperative serum gastrin assays are recorded in Table III. In addition, the approximate duration of gastrointestinal symptoms is recorded for each of the cases. It will be observed that the duration of symptoms in those cases with pancreatic tumour, or D cell hyperplasia, was longer than in the cases with $G$ cell hyperplasia. There is no absolute relationship, however, between the preoperative serum gastrin levels and the presumptive source of the hormone although there is a suggestion that in the short duration cases, with antral G cell hyperplasia, the levels tend to be higher.

\section{Discussion}

Our results support four important conclusions:

1 In duodenal ulcer there is a true but moderate hyperplasia of the antral $G$ cells, which are full of gastrin. This hyperplasia may involve duodenal $\mathbf{G}$ cells.

2 In pernicious anaemia there is a pronounced hyperplasia of the antral $\mathbf{G}$ cells. Their gastrin content is low, due, presumably, to lack of acid inhibition.

3 In cases of Z-E syndrome with antral G cell hyperplasia pancreatic $D$ cell hyperplasia is absent or minimal and there is no overt gastrinoma.

4 In cases of Z-E syndrome with either pancreatic $D$ cell hyperplasia, or pancreatic or extrapancreatic gastrinoma, the antral $\mathbf{G}$ cell population is within normal limits, both in number and cell size.

Our eight Z-E cases can thus be subdivided into two types, as shown in Table IV.

These results must be interpreted on the basis of a number of existing theories which endeavour to explain the pathogenesis of the Zollinger-Ellison

\begin{tabular}{|c|c|c|}
\hline Z-E Syndrome & Type 1 & Type 2 \\
\hline $\begin{array}{l}\text { History } \\
\text { Serum gastrin } \\
\text { Antral G cells } \\
\text { Pancreatic D cells } \\
\text { Tumour }\end{array}$ & $\begin{array}{l}\text { Short } \\
\text { Very high } \\
\text { Hyperplasia }+++ \\
\text { Normal or slightly }+ \\
\text { Absent }\end{array}$ & $\begin{array}{l}\text { Long } \\
\text { High } \\
\text { Normal } \\
\text { Hyperplasia } \\
\text { or gastrinoma }\end{array}$ \\
\hline
\end{tabular}

Table IV Two types of Zollinger-Ellison syndrome

syndrome, and also with respect to the concept of the neuro-endocrine nature and possible totipotentiality of the majority of endocrine polypeptide cells (Pearse, 1966, 1969; Sircus, 1969).

The factor responsible for the proliferation of $G$ cells has not been identified. A number of workers (Waddell, Leonsins, and Zuidema, 1959; Rudolph, Dammin, and Moore, 1960; Ptak and Kirsner, 1970) have supported the concept of primary hypothalamic overactivity, leading to excessive activity of the anterior pituitary gland, as the main factor. Pituitary hormones have been shown to influence gastric secretion (Kyle and Welbourn, 1956-57) and in pituitary insufficiency, in both man and animals, it is markedly reduced (Haeger, Jacobsohn, and Kahlson, 1953; Hirschowitz, 1957; Dotevall and Westling, 1963). After transauricular hypophysectomy a decrease in gastrin acid output was noted by Robert, Phillips, and Nezanis (1966). After administration of growth hormone, normal levels were restored. Increased gastric acid output has been observed in acromegaly, and immunofluorescence and ultrastructural studies revealing the underlying antral $G$ cell hyperplasia have been made by Pearse and Bussolati (1970) and by Creutzfeldt et al (1971). A pituitary influence on islet cells, and on endocrine polypeptide neoplasms, has been postulated by Friesen et al (1970) and by Friesen (1972) following the observation that after hypophysectomy in Z-E syndrome with tumour a decrease in the size of metastases was observed, together with a fall in serum gastrin levels.

\begin{tabular}{|c|c|c|c|}
\hline \multirow[t]{2}{*}{ Case Number and Description } & \multicolumn{2}{|c|}{ Gastrin Assay (pg/ml plasma) } & \multirow[t]{2}{*}{ Duration of Symptoms } \\
\hline & Preoperative & Postoperative & \\
\hline $1 \mathrm{G}$ cell hyperplasia & $\begin{array}{l}9150 \\
6750\end{array}$ & 118 & $2-3 \mathrm{yr}$ \\
\hline 2 Pancreatic gastrinoma & $\begin{array}{l}3720 \\
2433\end{array}$ & $\begin{array}{l}250 \\
158\end{array}$ & $9 \mathrm{yr}$ \\
\hline $\begin{array}{l}3 \text { Pancreatic gastrinoma } \\
4 \text { D cell hyperplasia }\end{array}$ & $\begin{array}{r}885 \\
1070\end{array}$ & $\begin{array}{l}\text { Died } \\
437 \\
425\end{array}$ & $\begin{array}{l}18 \mathrm{yr} \text { (acute, } 18 \mathrm{mth}) \\
10 \mathrm{yr}\end{array}$ \\
\hline $\begin{array}{l}5 \mathrm{G} \text { cell hyperplasia } \\
6 \mathrm{G} \text { cell hyperplasia } \\
7 \mathrm{Gastric} \text { gastrinoma } \\
8 \mathrm{G} \text { cell hyperplasia }\end{array}$ & $\begin{array}{l}9500 \\
2820 \\
1070 \\
2820\end{array}$ & $\begin{array}{l}\text { Died } \\
\text { 50 } \\
-\end{array}$ & $\begin{array}{l}6 \mathrm{yr} \\
4 \mathrm{yr} \\
40 \mathrm{yr}(\text { acute, } 10 \mathrm{mth}) \\
6 \mathrm{yr} \text { (acute } 12 \mathrm{mth})\end{array}$ \\
\hline
\end{tabular}

Table III Pre-and postoperative serum gastrin assays 
It is difficult to determine the exact incidence of pituitary abnormalities in the Z-E syndrome but pituitary tumours have been reported in at least $10 \%$ of Z-E patients (Ellison and Wilson, 1967) and in four out of 12 cases (33\%) by Friesen (1972). It is similarly difficult to ascertain the precise nature of pituitary abnormalities described in association with the Z-E syndrome. If the latter is potentially a generalized disorder of the whole group of endocrine polypeptide (APUD) cells then the ACTH cells (corticotrophs) of the pituitary should be the cells involved. Their hyperplasia would result in Cushing's syndrome, a known concomitant of the Z-E syndrome. If, on the other hand, this is a primary hypothalamic disorder then any of the trophic hormone cells of the pituitary could be implicated. Hyperplasia of the growth hormonesecreting acidophils would result in acromegaly, again known to accompany the Z-E syndrome. If the hypothalamic hypothesis is correct one would expect acromegaly in the Z-E syndrome to be more common, and of earlier onset, than ACTH cell hyperplasia and Cushing's syndrome. In our series there was no correlation between the type of gastrin cell abnormality and the presence or absence of associated endocrine disorders or abnormalities.

Our overall view, which closely follows concepts developed by Friesen $(1968,1972)$ is as follows:

1 In duodenal ulcer there is a stimulus to $G$ cell hyperplasia, which may affect both antrum and duodenum. The resulting hypersecretion of acid produces acid inhibition, which keeps the $G$ cells full of gastrin. The observation that the $G$ cells in duodenal ulcer were hyperplastic, in a high proportion of cases, was made by Solcia et al (1970). The report by Pearse, Coulling, Weavers, and Friesen (1970) that the hyperplastic antral G cells in duodenal ulcer cases were 'poorly granulated' was based on staining techniques. Clearly, as pointed out by Creutzfeldt et al (1971), immunofluorescence techniques provide a far more reliable indicator of the hormone content of the $\mathrm{G}$ cells.

2 In the Z-E syndrome there is a (pituitary) stimulus to $G$ cell hyperplasia, which gives rise to high acid output and consequent acid inhibition, with storage of gastrin in the hypertrophied G cells. This stimulus may conceivably act on the islet D cells, at the same time or later, to produce hyperplasia, and gastrin production not subject to acid inhibition. Overproduction of gastrin from hypertrophic $G$ cells, identified by staining techniques, was first postulated as a source of the high serum gastrin of the Z-E syndrome by Solcia et al (1970).

3 Antral inhibition (Friesen et al, 1970; Friesen, 1972) produces a negative feedback 'gastric factor' which may come from antrum, fundus, or duodenum and which stimulates the pituitary to further production of the gastrinotrophic principle.

4 This in turn stimulates the production of gastrin by cells other than those in the antrum. These are mainly the islet D cells but other (totipotent) endocrine polypeptide cells in a number of sites could be implicated. Both could be either hyperplastic or frankly neoplastic.

As we see it, the Z-E syndrome develops in two stages. The first includes antral and duodenal $G$ cell stimulation, with minimal extragastrointestinal involvement but with high acid output. While antral levels are clearly very high, the contribution of the $\mathrm{G}$ cells to the serum gastrin must involve their escape from acid inhibition. In the second stage extragastrointestinal sites of gastrin production will have

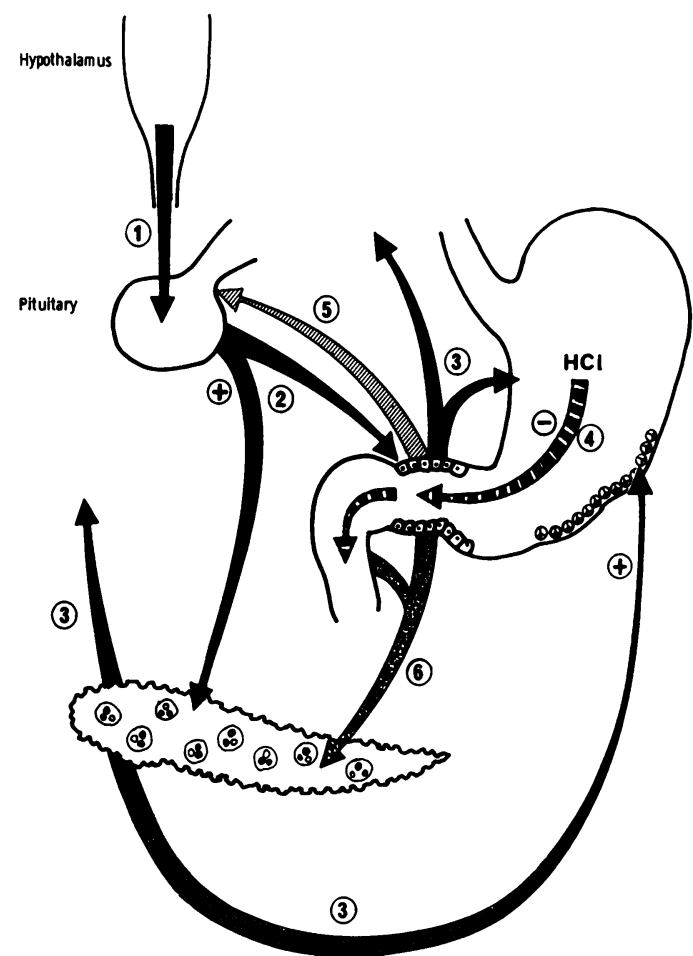

Fig. 12 Pathogenesis of the Zollinger-Ellison syndrome 1 Hypothalamic principle acting on anterior hypophysis. 2 Stimulating (gastrinotrophic) factor secreted by anterior hypophysis.

3 Gastrin production by islet $D$ cells and antral $G$ cells, stimulating.

4 Acid hypersecretion by the parietal cells. 5 Antral inhibition factor (Friesen, 1972) producing a negative feedback effect stimulating the further production of (2), the gastrinotrophic factor.

6 Possible action of antral inhibition factor on the islet cells of the pancreas. 


\begin{tabular}{|c|c|c|}
\hline Reaction or Property & Antral G Cells & Pancreatic D Cells \\
\hline $\begin{array}{l}\text { HCl-toluidine blue } \\
\text { Lead haematoxylin } \\
\text { Argyrophilia } \\
\text { Immunofluorescence }\end{array}$ & $\begin{array}{l}\text { Red (moderate) } \\
+ \text { (moderate) } \\
\text { Grimelius }+\end{array}$ & $\begin{array}{l}\text { Purple (without } \mathrm{HCl})^{2} \\
\text { Very weak }+ \\
\text { Hellerstrõm-Hellman }+\end{array}$ \\
\hline $\begin{array}{l}\text { Antihuman gastrin I } \\
\text { Antipentagstrin } \\
\text { Ultrastructure } \\
\text { (granules) }\end{array}$ & $\begin{array}{l}\text { MFF-paraffin sections }+3,4 \\
\text { Bouin-paraffin sections }+^{5} \\
\text { Osmiophilia }+ \\
\text { Average } 150-180 \mathrm{~nm}\end{array}$ & $\begin{array}{l}\text { Fresh-frozen (unfixed) }{ }^{6,7} \text { sections }+ \\
\text { Paraffin sections }- \\
\text { Osmiophilia }++ \\
\text { Average size } 180-350 \mathrm{~nm}\end{array}$ \\
\hline
\end{tabular}

Table V Characteristics of antral and pancreatic gastrin cells

'Solcia et al (1967)

'Manocchio (1964)

${ }^{3}$ Bussolati and Pearse (1970)

Polak, Bussolati, and Pearse (1971)

become activated and their output, uninhibited by high gastric acid levels, could form the major contribution to the serum gastrin. If this reasoning is correct, a third stage is required by our findings, in which the antral $G$ cell hyperplasia is reversed and the high serum gastrin is contributed wholly by non-gastric sources.

The foregoing observations are summarized in Figure 12. In this diagram the numbers attached to various arrows signify the order of precedence of the various factors, in terms of time of development, without prejudice to which pathway may be most important in the fully developed syndrome.

There remain, however, a number of observations which are not satisfactorily explained by the diagram. In terms of our own findings it is difficult to see why the antral $\mathrm{G}$ cells should return to normal after stage 2 and the correct explanation may be that our two groups are really alternative types of the syndrome rather than successive stages, depending on which group of endocrine polypeptide cells first respond to the 'primary' pituitary stimulus.

There are many reasons for supposing that the the two types of gastrin-secreting cell might respond in different ways to the same stimulus. Cytochemical investigations show clearly that the storage form of gastrin in the antral $G$ cells is quite different from that in the islet $\mathrm{D}$ cells. These differences are summarized in Table $\mathrm{V}$.

It is possible that most of these differences reflect differences in the lipoprotein envelope and matrix of the $G$ and $D$ cell granules. This would accord with the views of Koenig (Koenig, 1962, 1965; Mylroie and Koenig, 1971) on the role of lipoproteins in the metachromasia of various types of storage granules with basic dyes. On the other hand they may indicate, as the differing effects of fixation strongly suggest, differences in the composition of the stored polypeptide or protein. If this is so, the time may well be ripe for a reinvestigation of pancreatic gastrin since if, by analogy with insulin, the pro-
${ }^{\circ}$ Creutzfeldt et al (1971)

${ }^{\circ}$ Greider and McGuigan (1971)

'Present observations

gastrin part of the molecule is distinct from the antral progastrin fragment, then a distinction could be made between high serum antral gastrin and high serum pancreatic gastrin by assays distinguishing the two inactive fragments.

Our observations, which suggest that antral gastrin should be high in duodenal ulcer cases, are supported by the findings of Hansky, Korman, Cowley, and Baron (1971) that after stimulation by insulin or bicarbonate the serum gastrin levels in duodenal ulcer patients are much higher than in control cases. The difference between the antrum in duodenal ulcer and in the $G$ cell hyperplasia cases of the Z-E syndrome is shown by our studies to be one of degree only. Thus the profound differences in serum gastrin levels in the two conditions must be due to escape of the $G$ cells from acid inhibition in the Z-E cases unless, and this seems basically unlikely, there exists a source of gastrin within or outside the pancreas, which we and others have failed to detect.

We are grateful especially, among a number of clinicians and pathologists who have helped us by providing access to their material, to $\mathrm{Mr}$ John Spencer, Dr J. Gosling, and Dr A. M. Dawson. For assistance with the quantitative work we are indebted to Mr F. Paice of the MRC Cyclotron Unit, Hammersmith Hospital, with the radioimmunoassays to Dr M. R. Lewin of the Surgical Unit, University College Hospital, for the electron microscopy to Miss C. Heath, and for the line drawings to Mr P. Clark, medical artist, R.P.M.S.

The work was carried out with the aid of a grant from the Wellcome Trust.

\section{References}

Bloom, W. (1931). New type of granular cell in islets of Langerhans of man. Anat. Rec., 49, 363-371.

Bussolati, G., and Pearse, A. G. E. (1970). Immunofluorescent localization of the gastrin-secreting $\mathbf{G}$ cells in the pyloric antrum of the pig. Histochemie, 21, 1-4. 
Cavallero, C., and Solcia, E. (1964). Cytologic and cytochemical studies on the pancreatic islets. In The Structure and Metabolism of the Pancreatic Islets, edited by S. E. Brolin, B. Hellman and $H$. Knutson, pp. 83-97. Pergamon, Oxford.

Cavallero, C., Solcia, E., and Sampietro, R. (1967). Cytology of islet tumours and hyperplasias associated with the ZollingerEllison syndrome. Gut, 8, 172-177.

Coons, A. H., Leduc, E. H., and Connolly, J. M. (1955). Studies on antibody production. I: A method for the histochemical demonstration of specific antibody and its application to a study of the hyperimmune rabbit. J. exp. Med., 102, 49-60.

Creutzfeldt, W., Arnold, R., Creutzfeldt, C., Feurle, G., and Ketterer, H. (1971). Gastrin and G cells in the antral mucosa of patients with pernicious anaemia, acromegaly and hyperparathyroidism and in a Zollinger-Ellison tumour of the pancreas. Europ. $J$. clin. Invest., 1, 461-479.

Deconinck, J. F., Potvliege, P. R., and Gepts, W. (1971). The ultrastructure of the human pancreatic islets. I. The islets of adults. Diabetologia, 7, 266-282.

Dotevall, G., and Westling, H. (1963). Gastric acid secretion before and after hypophysectomy in man. Acta med. scand., 174, 777-780.

Ellison, E. H., and Wilson, S. D. (1964). The Zollinger-Ellison syndrome: reappraisal and evaluation of 260 registered cases. Ann. Surg., 160, 512-530.

Ellison, E. H., and Wilson, S. D. (1967). The Zollinger-Ellison syndrome updated. Surg. clin. N. Amer., 47, 1115-1124.

Forty, F., and Barrett, G. M. (1952). Peptic ulceration of the third part of duodenum, associated with islet cell tumours of the pancreas. Brit. J.Surg., 40, 60-63.

Friesen, S. R. (1972). Zollinger-Ellison Syndrome. In Current Problems in Surgery, pp. 3-52. Year Book Inc., Chicago.

Friesen, S. R., Bolinger, R. E., Pearse, A. G. E., and McGuigan, J. E. (1970). Serum gastrin levels in malignant ZollingerEllison syndrome after total gastrectomy and hypophysectomy. Ann. Surg., 172, 504-521.

Fujita, T. (1964). The identification of the argyrophil cells of pancreatic islets with D cells. Arch. Histol. jap., 25, 189-197.

Fujita, T. (1968). D cell, the third endocrine element of the pancreatic islet. Arch. Histol. jap., 29, 1-40.

Gomori, G. (1952). Microscopic Histochemistry. University of Chicago Press, Chicago.

Goodfriend, T. L., Levine, L., and Fasman, G. D. (1964). Antibodies to bradykinin and angiotensin: a use of carbodiimides in immunology. Science, 144, 1344-1346.

Gregory, H., Hardy, P. M., Jones, D. S., Kenner, G. W., and Sheppard, R. C. (1964). Structure of gastrin. Nature (Lond.), 204, 931-933.

Gregory, R. A., Grossman, M. I., Tracy, H. J., and Bentley, P. H. (1967). Nature of the gastric secretagogue in Zollinger-Ellison tumours. Lancet, 2, 543-544.

Gregory, R. A., and Tracy, H. J. (1964). A note on the nature of the gastrin-like stimulant present in Zollinger-Ellison tumours. Gut, 5, 115-117.

Gregory, R. A., Tracy, H. J., French, J. M., and Sircus, W. (1960). Extraction of a gastrin-like substance from a pancreatic tumour in a case of Zollinger-Ellison syndrome. Lancet, 1 , 1045-1048.

Greider, M. H., Bencosme, S. A., and Lechago, J. (1970). The human pancreatic islet cells and their tumors. I. The normal pancreatic islets. Lab. Invest., 22, 344-354.

Greider, M. H., and McGuigan, J. E. (1971). Cellular localization of gastrin in the human pancreas. Diabetes, 20, 389-396.

Grimelius, L. (1968). A silver nitrate stain for alpha-2 cells in human pancreatic islets. Acta Soc. Med. upsalien, 73, 243-270.

Grossman, M. I., Tracy, H. J., and Gregory, R. A. (1961). ZollingerEllison syndrome in a Bantu woman, with isolation of a gastrinlike substance from the primary and secondary tumors. II. Extraction of gastrin-like activity from tumors. Gastroenterology, 41, 87-91.

Guida, P. M., Todd, J. E., Moore, S. W., and Beal, J. M. (1966). Zollinger-Ellison syndrome with interesting variations. Amer. J. Surg., 112, 807-817.

Haeger, K., Jacobsohn, D., and Kahlson, G. (1953). Atrophy of the gastrointestinal mucosa following hypophysectomy or adrenalectomy. Acta physiol. scand., 30, Suppl. 111, 161-169.

Hallenbeck, G. A. (1966). Gastrin-like activity of activity of tumors A review in Gastrin, edited by M. I. Grossman, pp. 285-308. UCLA Forum in Medical Sciences, No. 5. University of California Press, Berkeley.
Hansky, J., Korman, M. G., Cowley, D. J., and Baron, J. (1971). Serum gastrin in duodenal ulcer. II. Effect of insulin hypoglycaemia. Gut, 12, 959-962.

Hellman, B., Rothman, U., and Hellerström, C. (1962). Identification of a specific type of $\alpha$ cell located in the central part of the pancreatic islet of the horse. Gen. comp. Endocr., 2, 558-564.

Herbert, V., Lau, K.-S., Gottlieb, C. W., and Bleicher, S. J. (1965), Coated charcoal immunoassay of insulin. J. clin. Endocr., 25, 1375-1384.

Hirschowitz, B. I. (1957). Pepsinogen: its origins, secretion and excretion. Physiol. Rev., 37, 475-511.

Hunter, W. M., and Greenwood, F. C. (1962). Preparation of iodine131 labelled human growth hormone of high specific activity. Nature (Lond.), 194, 495-496.

Koenig, H. (1962). Histological distribution of brain gangliosides: Lysosomes as glycolipoprotein granules. Nature (Lond.), 195, $782-784$.

Koenig, H. (1965). Metachromatic staining of catecholamine storage particles by basic dyes. J. Histochem. Cytochem., 13, 706-707.

Kyle, J., and Welbourn, R. B. (1956-57). The influence of the adenohypophysis and the adrenal cortex on gastric secretion in the rat. Brit. J. Surg., 44, 241-247.

Lomský, R., Langr, F., and Vortel, V. (1969). Immunohistochemical demonstration of gastrin in mammalian islets of Langerhans. Nature (Lond.), 223, 618-619.

McGuigan, J. E. (1968). Gastric mucosal intracellular localization of gastrin by immunofluorescence. Gastroenterology, 55, 315-327.

McGuigan, J. E, and Trudeau, W. L. (1968). Immunochemical measurement of elevated levels of gastrin in the serum of patients with pancreatic tumors of the Zollinger-Ellison variety. New Engl. J. Med., 278, 1308-1313.

Manocchio, I. (1964). The metachromatic A-cells in the pancreatic islets of dogs of different ages. In The Structure and Metabolism of the Pancreatic Islets, edited by S. E. Brolin, B. Hellman, and $\mathrm{H}$. Knutson, pp. 105-116. Pergamon, Oxford.

Millonig, G. (1962). Further observations on a phosphate buffer for osmium solutions in fixation. In Proceedings of the International Congress for Electron Microscopy, Philadelphia, edited by Sydney S. Breese, Jr., p. 8. Academic Press, New York.

Mylroie, R., and Koenig, H. (1971). Soluble acidic lipoproteins of bovine neurosecretory granules. Relation to neurophysics. J. Histochem. Cytochem., 19, 738-746.

Pearse, A. G. E. (1960). Histochemistry, Theoretical and Applied, 2nd ed. Churchill, London.

Pearse, A. G. E. (1966). Common cytochemical properties of cells producing polypeptide hormones, with particular references to calcitonin and the thyroid C cells. Vet. Rec., 79, 587-590.

Pearse, A. G. E. (1969). The cytochemistry and ultrastructure of polypeptide-hormone-producing cells of the APUD series, and the embryologic, physiologic and pathologic implications of the concept. J. Histochem. Cytochem., 17, 303-313.

Pearse, A. G. E. (1972). Histochemistry, Theoretical and Applied, 3rd ed., Vol. 2. Churchill Livingstone, London.

Pearse, A. G. E., and Bussolati, G. (1970). Immunofluorescence studies of the distribution of gastrin cells in different clinical states. Gut, 11, 646-648.

Pearse, A. G. E., Coulling, I., Weavers, B., and Friesen, S. (1970). The endocrine polypeptide cells of the human stomach, duodenum and jejunum. Gut, 11, 649-658.

Peterson, B., Hellerström, C., and Hellman, B. (1962). Some characteristics of the two types of A-cells in the islets of Langerhans of guinea pigs. $Z$. Zellforsch., 57, 559-566.

Polak, J. M., Bloom, S., Coulling, I., and Pearse, A. G. E. (1971) Immunofluorescent localization of enteroglucagon cells in the gastrointestinal tract of the dog. Gut, 12, 311-318.

Polak, J. M., Bussolati, G., and Pearse, A. G. E. (1971). Cytochemical, immunofluorescence and ultrastructural investigations on the antral $G$ cells in hyperparathyroidism. Virchows Arch. Abt. B. Zell. path., 9, 187-197.

Poth, E. J., Manhoff, L. J., and Deloach, A. W. (1948). The relation of pancreatic secretion to peptic ulceration. Surgery, 24, 62-69.

Priest, W. M., and Alexander, M. K. (1957). Islet cell tumour of the pancreas with peptic ulceration, diarrhoea and hypokalaemia. Lancet, $2,1145-1147$.

Ptak, T., and Krisner, J. B. (1970). The Zollinger-Ellison syndrome, polyendocrine adenomatosis and other endocrine associations with peptic ulcer. Advanc. intern. Med., 16, 213-242.

Robert, A., Phillips, J. P., and Nezaims, J. E. (1966). Gastric secretion and ulcer formation after hypophysectomy and admin- 
istration of somatotrophic hormone. Amer. J. dig. Dis., 11, 546-552.

Rudolph, L. E., Dammin, G. F., and Moore, F. D. (1960). Intractable peptic ulcer and endocrine adenomas with pituitary amphophilic hyperplasia. Surgery, 48, 170-184.

Sailer, S., and Zinninger, M. M. (1946). Massive islet cell tumor of pancreas without hypoglycemia. Surg. Gynec. Obstet., 82, 301-305.

Selli, M., Baglioni, A., and Castrini, G. (1963). La sindrome di Zollinger Ellison (rassegna siutetica-contributo clinico). Chir. gen. (Perugia), 12, 117-155.

Sevier, A. C., and Munger, B. L. (1965). Technical note: a silver method for paraffin sections of neural tissue. J. Neuropath. exp. Neurol., 24, 130-135.

Sircus, W. (1964). Evidence for a gastric secretagogue in the circulation and gastric juice of patients with the Zollinger-Ellison syndrome. Lancet, 2, 671-672.

Sircus, W. (1969). Peptide-secreting tumours with special reference to the pancreas. Gut, 10, 506-515.

Solcia, E., Capella, C., and Vassallo, G. (1969a). Lead-haematoxylin as a stain for endocrine cells. Significance of staining and comparison with other selective methods. Histochemie, 20, 116-126.

Solcia, E., Capella, C., and Vassallo, G. (1970). Endocrine cells of the stomach and pancreas in states of gastric hypersecretion. Rendic. R. Gastroenterol., 2, 147-158.

Solcia, E., and Sampietro, R. (1965). On the nature of the metachromatic cells of pancreatic islets. Z. Zellforsch., 65, 131-138.

Solcia, E., Sampietro. R., and Capella, C. (1969b). Differential staining of catecholamines, 5-hydroxytryptamine and related com- pounds in aldehyde-fixed tissue. Histochemie, 17, 273-283, Solcia, E., Vassallo G., and Capella, C. (1968). Selective staining of endocrine cells by basic dyes acid hydrolysis. Stain Technol. 43, $257-263$.

Solcia, E., Vassallo, G., and Sampietro, R. (1967). Endocrine cells in the antro-pyloric mucosa of the stomach. Z. Zellforsch., 81, 474-486.

Strom, R. (1953). Case of peptic ulcer and insuloma. Acta chir. scand., 104, 252-260.

Summerskill, W. H. J. (1959). Malabsorption and jejunal ulceration due to gastric hypersecretion with pancreatic islet-cell hyperplasia. Lancet, 1, 120-123.

Takaya, K. (1970). A new fluorescent stain with $O$-phthalaldehyde for A cells of the pancreatic islets. J. Histochem. Cytochem., 18, 178-186.

Terner, J. Y., Gurland, J., and Gaer, F. (1964). Phosphotungstic acid hematoxylin: spectrophotometry of the lake in solution and in stained tissue. Stain Technol., 39, 141-153.

Thomas. T. B. (1937). Cellular components of the mammalian islets of Langerhans. Amer. J. Anat., 62, 31-57.

Waddell, W. R., Leonsins, A. J., and Zuidema, G. D. (1959). Gastric secretory and other laboratory studies on two patients with Zollinger-Ellison syndrome. New Engl. J. Med., 260, 56-62.

Zollinger, R. M., Elliott, D. W., Endahl, G. L., Grant, G. N., Goswitz, J. T., and Taft, D. A. (1962). Origin of the ulcerogenic hormone in endocrine induced ulcer. Ann. Surg., 156, 570-578.

Zollinger, R. M., and Ellison, E. H. (1955). Primary peptic ulcerations of the jejunum associated with islet cell tumors of the pancreas. Ann. Surg., 142, 709-728. 